\title{
PEMANFAATAN SERBUK GERGAJI KAYU JATI (TECTONA GRANDIS L.F) SEBAGAI ADSORBEN LOGAM CU (II)
}

\author{
Gusti Ayu Arini \& Sitti Aminah \\ Jurusan Pendidikan MIPA \\ Fakultas Keguruan dan IImu Pendidikan Universitas Tadulako Palu
}

\begin{abstract}
Sawdust is one of the industrial wastes that can be used as an absorbent. The chemical content in sawdust is the same as in its wood, i.e lignin, cellulose, and hemicellulose. This study aimed to determine the optimum contact time, optimum weight, and adsorption capacity of $\mathrm{Cu}$ (II) ions by teak sawdust using the atomic absorption spectrophotometry (AAS). Determination of optimum contact time was carried out with time variations of 10, 30 and 60 minutes, the optimum weight with various weight of $0.5,1$, and 1.5 grams, and the adsorption capacity of teak sawdust in various concentrations of 50, 100, 150 and $200 \mathrm{ppm}$. The results showed that the equilibrium contact time was reached at 30 minutes, and the percentage of adsorption of $\mathrm{Cu}$ (II) was $91.25 \%$. The optimum weight for metal adsorption was 1.5 gram, and the adsorption percentage of adsorbed $\mathrm{Cu}$ (II) ions was $96.18 \%$. The adsorption capacity was determined from the adsorption isotherm according to the Langmuir and the freundlich models. The adsorption isotherm model of $\mathrm{Cu}$ (II) of teak sawdust follows the Langmuir isotherm model with a maximum adsorption capacity (qmax) of $2.058 \mathrm{mg} / \mathrm{g}$.
\end{abstract}

Keywords: Adsorption, teak sawdust, $\mathrm{Cu}$ (II) ions, Atomic Absorption Spectrophotometry (AAS)

\section{PENDAHULUAN}

Pencemaran lingkungan oleh logam berat merupakan masalah yang serius saat ini karena sifat akumulasi logam tersebut dalam rantai makanan dan persistensinya di dalam ekosistem. Saat ini dengan perkembangan industri seperti; elektrokimia, kulit, hidrometalurgi, pelapisan tekstil, plastik, kosmetik, kertas, pupuk buatan dan industri lainnya, maka semakin banyak logam berat yang dibuang ke lingkungan sehingga menjadi masalah di seluruh dunia karena sifatnya tidak mengalami degradasi (penguraian), tidak dapat dihancurkan dan karsinogenisitas. Menimbang bahaya dan kerugian yang ditimbulkan oleh logam berat maka berbagai teknik telah diaplikasikan diantaranya adalah adsorpsi, proses presipitasi, filtrasi, elektrokimia, reverse osmosis, oksidasi/reduksi, pertukaran ion, penguapan dan teknologi membran (Deng dkk., 2016).

Logam-logam berat yang terlarut dalam badan perairan pada konsentrasi tertentu dapat berubah fungsi menjadi sumber racun bagi kehidupan perairan. Meskipun daya racun yang ditimbulkan oleh satu jenis logam berat terhadap semua biota tidak sama, namun kehilangan dari satu kelompok dapat menyebabkan terputusnya satu mata rantai kehidupan. Pada tingkat selanjutnya, keadaan tersebut tentu saja dapat menghancurkan satu tatanan ekosistem perairan (Palar, 1994).

Berkembangnya penggunaan bahan industri yang menghasilkan limbah cair yang mengandung residu organik dan anorganik akan mengakibatkan potensi atau dampak negatif bagi lingkungan dan kesehatan manusia, maka menjadi solusi yang wajib untuk mengurangi atau menghapuskan polutan (Irawati., dkk 2016).

Perkembangan industri yang makin pesat menyebabkan semakin banyak pula bahan buangan yang bersifat racun yang dibuang ke lingkungan, yang nantinya akan mencemari lingkungan dalam jumlah yang sulit di kontrol secara tepat. Di Indonesia, sumber pencemar dapat berasal dari limbah rumah tangga, perusahaan-perusahaan, pertambangan, industri dan lain-lain (Tangio, 2013). Salah satu limbah industry yang banyak ditemui adalah serbuk gergaji. Limbah ini banyak menimbulkan masalah dalam penangannya yang selama ini dibiarkan membusuk, ditumpuk, dan dibakar yang berdampak negative terhadap lingkungan.

Sebuk gergaji merupakan salah satu limbah industri yang dapat dimanfaatkan sebagai zat penyerap (adsorben). Serbuk gergaji merupakan hasil samping dari industri kayu. (Purwaningsih, 2009). Jumlah limbah serbuk kayu gergaji yang ada di Indonesia sebesar 0,78 juta $\mathrm{m}^{3} /$ tahun (Mutiara dkk, 2016). Serbuk gergaji kayu mengandung selulosa, hemilosa dan lignin. Adanya gugus $-\mathrm{OH}$ pada selulosa menjadikan serbuk gergaji kayu dapat digunakan sebagai adsorben ion logam. (Zubaidah dkk., 2017)

Metode adsorpsi merupakan metode penyerapan yang paling umum dipakai karena memiliki konsep yang lebih sederhana, tidak menimbulkan efek samping yang beracun, dapat diregenerasi, serta ekonomis. Waktu kontak merupakan salah satu hal yang menentukan dalam proses adsorpsi. Gaya adsorpsi molekul dari suatu zat terlarut akan meningkat apabila waktu kontaknya dengan adsorben makin lama. Teknik adsorpsi terhadap logam berat dapat dilakukan dengan menggunakan berbagai macam adsorben dengan memanfataan limbah organik seperti jerami padi, kulit batang jambu biji, karbon aktif tongkol jagung, pektin dan serbuk gergaji (Fatmi, 2018). 
Tembaga $(\mathrm{Cu})$ merupakan salah satu logam berat yang digunakan secara luas pada industri listrik, fungisida dan cat anti cemar. Ketika $\mathrm{Cu}$ masuk ke dalam tubuh pada konsentrasi tinggi dapat mengakibatkan racun pada manusia antara lain liver, penyakit mental (schizophrenia) dan kanker. Penyebaran logam $\mathrm{Cu}$ mendapat perhatian para pemerhati lingkungan, karena sifat logam ini berbahaya bagi manusia, tanaman, dan makhluk hidup lainnya. Kesulitan dalam pengolahan limbah yang mengandung logam berat disebabkan oleh bentuk dan kandungan logam berat dalam limbah yang sangat bervariasi, yang dapat merusak ekosistem kehidupan yang ada disekitarnya (Widodo, 2008).

Berbagai metode telah dikembangkan untuk memisahkan logam berat dari air limbah, antara lain meliputi metoda pengendapan kimia, filtrasi mekanik, penukar ion, elektrodeposisi, oksidasi reduksi, sistem membran, adsorpsi fisik, evaporasi, elektrokimia, dan dengan cara penyerapan bahan pencemar oleh adsorben baik berupa resin sintetik maupun karbon aktif (Tekker,1999).

Pemanfaatan serbuk gergaji dari kayu jati sebagai adsorben logam berat masih terbatas pada beberapa logam berat saja, seperti timbal $(\mathrm{Pb})$, cadmium $(\mathrm{Cd})$, dan besi $(\mathrm{Fe})$. Oleh karena itu peneliti tertarik untuk melakukan penelitian mengenai "Pemanfaatan Serbuk Gergaji Kayu Jati Sebagai Adsorben Logam Cu"

\section{METODE}

Alat - alat yang digunakan pada penelitian ini adalah Spektrofotometer Serapan Atom (SSA) oven, neraca analitik, lumpang dan alu, corong, gelas ukur $50 \mathrm{~mL}, \mathrm{pH}$ meter, cawan porselen, gelas piala $1.000 \mathrm{~mL}$ dan $250 \mathrm{~mL}$, toples, saringan 70 mesh, Erlenmeyer $100 \mathrm{~mL}$, magnetic stirrer, labu ukur $500 \mathrm{~mL}, 250$ dan $50 \mathrm{~mL}$, pompa vakum, botol semprot, batang pengaduk, spatula, pipet tetes, dan stopwatch.

Bahan - bahan yang digunakan dalam penelitian ini adalah aquades, sampel serbuk gergaji kayu jati, kertas label, tissue, $\mathrm{CuSO}_{4} 5 \mathrm{H}_{2} \mathrm{O}$, dan kertas saring.

\section{Preparasi adsorben}

Serbuk gergaji kayu jati ditimbang 100 gram, setelah itu dihaluskan menggunakan lumpang dan alu, kemudian diayak dengan menggunakan ayakan 70 mesh, selanjutnya dimasukkan dalam gelas piala ukuran $1.000 \mathrm{~mL}$, dan ditambahkan aquades sebanyak $500 \mathrm{~mL}$. Campuran tersebut diaduk selama 3 jam, aquades yang dipakai untuk mencuci diganti setiap satu jam pengadukan menggunakan stirer, Setelah itu serbuk gergaji disaring menggunakan pompa vakum pump kemudian dikeringkan di oven pada suhu $105^{\circ} \mathrm{C}$ selama \pm 24 jam. Setelah dikeringkan, adsorben ditimbang, dan tahap terakhir yang dilakukan adalah menyimpan adsorben serbuk gergaji kayu jati tersebut didalam wadah yang kedap udara (toples) (Lelifajri,2010).
Penentuan waktu optimum adsorpsi ion $\mathrm{Cu}$ (II) oleh serbuk gergaji kayu jati

Kedalam 3 buah Erlenmeyer ukuran $100 \mathrm{~mL}$ dimasukkan masing-masing 0,5 gram adsorben (serbuk kayu jati), selanjutnya $25 \mathrm{~mL}$ larutan $\mathrm{Cu}$ (II) dengan konsentrasi $50 \mathrm{ppm}$ dimasukkan ke dalam Erlenmeyer ukuran $100 \mathrm{~mL}$ tersebut dan diaduk menggunakan magnetic stirrer masing-masing selama 10, 30, dan 60 menit. Kemudian campuran tersebut disaring menggunakan kertas saring dan filtratnya ditampung untuk diukur kadar tembaganya $\left(\mathrm{Cu}^{2+}\right)$ dengan SSA. Setiap percobaan dilakukan 3 kali pengulangan. (Lelifajri,2010)

\section{Penentuan berat adsorben optimum pada adsopsi Cu (II)}

Ke dalam 3 buah Erlenmeyer ukuran $100 \mathrm{~mL}$ dimasukkan masing-masing 0,5, 1,0, dan 1,5 gram serbuk kayu jati, selanjutnya $25 \mathrm{~mL}$ larutan Cu (II) dengan konsentrasi $50 \mathrm{ppm}$ dimasukkan kedalam Erlenmeyer ukuran $100 \mathrm{~mL}$ tersebut dan diaduk selama waktu kontak optimum. Kemudian campuran tersebut disaring menggunakan kertas saring dan filtratnya ditampung untuk diukur kadar tembaganya $\left(\mathrm{Cu}^{2+}\right)$ dengan SSA. Setiap percobaan dilakukan 3 kali pengulangan.

\section{Penentuan kapasitas adsorpsi ion $\mathrm{Cu}$ (II) oleh serbuk gergaji kayu jati}

Ke dalam 4 buah Erlenmeyer ukuran $100 \mathrm{~mL}$, dimasukkan masing-masing sebanyak massa optimum serbuk kayu jati. Selanjutnya, ke dalam Erlenmeyer tersebut dimasukkan secara berturutturut $25 \mathrm{~mL}$ larutan ion logam $\mathrm{Cu}(\mathrm{II})$ dengan konsentrasi 50, 100, 150 dan 200 mg/L. Campuran tersebut diaduk selama waktu kontak optimum, kemudian disaring dan filtratnya ditampung untuk diukur kadar tembaganya $\left(\mathrm{Cu}^{2+}\right)$ dengan SSA. Kadar $\mathrm{Cu}(\mathrm{II})$ pada larutan $\mathrm{Cu}(\mathrm{II})$ sebelum adsorpsi juga diukur. Selain itu dilakukan pengukuran $\mathrm{pH}$ pada sampel sebelum dan sesudah adsorpsi berlangsung.Setiap percobaan dilakukan 3 kali pengulangan (Lelifajri,2010).

\section{Teknik Analisis Data}

Data yang diperoleh dari hasil pengukuran konsentrasi logam dengan menggunakan spektrofotometer serapan atom dianalisis dengan langkah berikut :

Menghitung konsentrasi tembaga yang terserap (Cb) oleh adsorben (serbuk gergaji kayu jati) dengan menggunakan rumus (atkins, 1999) sebagai berikut

$$
\mathrm{Cb}=\mathrm{Ci}-\mathrm{Ceq}
$$

\section{Dimana :}

$\mathrm{Cb}=$ Konsentrasi tembaga yang terserap $(\mathrm{mg} / \mathrm{L})$

$\mathrm{Ci}=$ Konsentrasi larutan Cu mula mula (mg/l)

$\mathrm{Ceq}=$ Konsentrasi larutan $\mathrm{Cu}$ yang tidak terserap $(\mathrm{mg} / \mathrm{L})$ 
Menghitung persentase konsentrasi $\mathrm{Cu}$ yang terserap oleh serbuk gergaji kayu jati dengan menggunakan persamaan:

$$
\% \text { konsentrasi } C u=\frac{C b}{C i} \times 100 \%
$$

Dimana:

$\mathrm{Cb}=$ Konsentrasi tembaga yang terserap ( $\mathrm{mg} / \mathrm{L})$

$\mathrm{Ci}=$ Konsentrasi tembaga mula mula $(\mathrm{mg} / \mathrm{L})$

Kapasitas Adsorpsi

Kapasitas adsorpsi ditentukan dengan menggunakan persamaan:

$$
\begin{gathered}
\mathrm{Qe}=\frac{(\mathrm{Co}-\mathrm{Ce}) \times \mathrm{V}}{m} \text { atau } \\
\mathrm{Qe}=\frac{C \mathrm{~b} \mathrm{Cu}(\mathrm{II}) \times \mathrm{V}}{m}
\end{gathered}
$$

Dimana :

$\mathrm{Qe}=$ Kapasitas Adsorpsi (mg/g adsorben)

$\mathrm{Cb}=$ Jumlah $\mathrm{Cu}$ yang terserap $(\mathrm{mg} / \mathrm{L})$

$\mathrm{V}=$ Volume larutan $(\mathrm{L})$

$\mathrm{m}$ = Massa adsorben yang digunakan (g) (Garba dkk., 2016).

\section{Isoterm Adsorpsi}

Model Isoterm Langmuir digunakan untuk menentukan kapasitas adsorpsi maksimum dengan persamaan bentuk linear sebagai berikut:

Dimana :

$$
\frac{C e}{q e}=\frac{1}{b q m}+\frac{c e}{q m}
$$

$\mathrm{Ce}=$ konsentrasi kesetimbangan $(\mathrm{mg} / \mathrm{L})$ qe = jumlah zat terserap per gram adsorben (mg/g

qm = kapasitas adsorpsi $(\mathrm{mg} / \mathrm{g})$, dan

b = konstanta Langmuir (L/mg) (Deniz dkk, 2011).

Model persamaan Freundlich

$$
\log q e=\log K_{F}+1 / n \log C e
$$

\section{Dimana}

qe : berat zat yang di adsorpsi per gram adsorben (mg/g),

$\mathrm{Ce}$ : konsentrasi zat $(\mathrm{mg} / \mathrm{L})$,

$\mathrm{KF}$ : kapasitas adsorpsi (mg/g) dan

$\mathrm{n}$ : konstanta Freundlich (mg/g). (Garba dkk, 2016).

\section{HASIL DAN PEMBAHASAN}

Sampel serbuk gergaji kayu jati (Tectona Grandis L.f) yang diperoleh dari salah satu mebel yang berada di kota Tentena, Sulawesi Tengah. Hasil dari preparasi $100 \mathrm{~g}$ serbuk gergaji kayu jati diperoleh 41,93 g serbuk gergaji yang siap digunakan sebagai adsorben ion $\mathrm{Cu}$. Kadar $\mathrm{Cu}$ dalam larutan diukur menggunakan alat Spektrofotometer Serapan Atom.

Penentuan waktu optimum adsorpsi ion $\mathrm{Cu}$ (II) oleh serbuk gergaji kayu jati

Penentuan waktu pengocokan optimum pada penelitian ini dilakukan mulai dari waktu 10 menit, 30 menit, dan 60 menit, dimana konsentrasi larutan yang digunakan adalah 50 ppm. Data hasil pengukuran waktu optimum biosorpsi ion $\mathrm{Cu}(\mathrm{II})$ oleh serbuk gergaji kayu jati dapat dilihat pada Tabel 1.

\begin{tabular}{cc}
\hline Waktu (menit) & Cu terserap (\%) \\
\hline 10 & 87,20 \\
30 & 91,25 \\
60 & 89,28 \\
\hline
\end{tabular}

Tabel 1. Hasil Pengukuran waktu optimum adsorpsi ion cu(II)

Waktu kontak merupakan salah satu faktor yang mempengaruhi proses adsorpsi, karena melalui proses kontak penjerapan terjadi sebagai akibat dari interaksi fisik antara adsorbat dengan adsorben. Pada penelitian ini, variasi waktu yang digunakan pada proses adsorpsi adalah 10, 30, dan 60 menit. Konsentrasi larutan $\mathrm{Cu}$ (II) yang digunakan 50 ppm sebanyak $25 \mathrm{~mL}$, berat adsorben yang digunakan yaitu 0,5 gram. Berdasarkan data tersebut maka presentase adsorpsi pada berbagai waktu pengocokan dapat kita ilustrasikan seperti pada Gambar 1

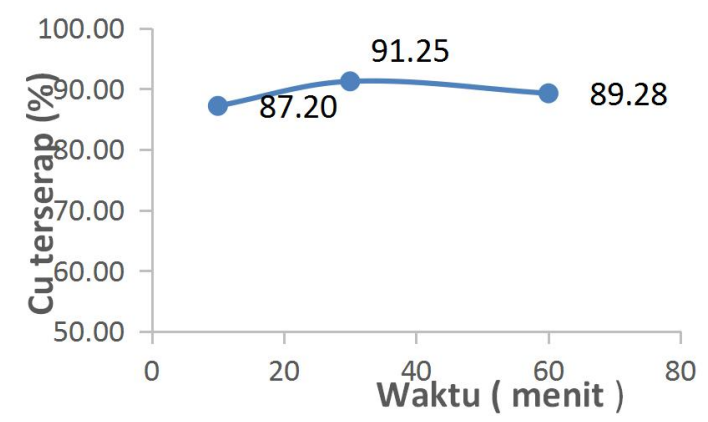

Gambar 1. Kurva hubungan antara waktu pengocokan terhadap \% Cu (II) terserap 
Kurva diatas menunjukan bahwa proses adsorpsi berlangsung dengan cepat pada awal kontak antara permukaan adsorben dengan sejumlah adsorbat. Hal ini dikarenakan ketersediaan permukaan aktif pada permukaan adsorben yang masih banyak. Penyerapan yang cepat biasanya dikarenakan oleh proses difusi yang terjadi antara adsorbat dengan permukaan adsorben. Pada menit 30 serapan Cu (II) relatif meningkat karena interaksi antara ion logam dan adsorben terjadi secara efektif. Hal ini disebabkan karena semua sisi aktif yang terdapat pada adsorben saling berikatan dengan ion-ion $\mathrm{Cu}$ dalam larutannya. Selanjutnya proses adsorpsi berlangsung dengan konstan sampai permukaan adsorben jenuh dan tidak dapat menyerap lagi. (Pongenda dkk., 2015).

Berdasarkan Gambar 1, kita ketahui bahwa waktu pengocokan selama 10 menit dapat menyerap Cu (II) sebesar $87,20 \%$, dan mencapai optimum pada waktu 30 menit dengan penyerapan $91,25 \%$, sedangkan pada waktu pengocokan 60 menit didapatkan penurunan penyerapan yaitu $89,28 \%$. Hal ini dikarenakan permukaan aktif pada adsorben sudah cukup jenuh sehingga tidak memungkinkan untuk menyerap adsorbat lebih banyak.
Waktu adsorpsi berpengaruh terhadap presentase adsorpsi. Pada awal kenaikan waktu adsorpsi akan menaikkan efisiensi adsorpsi ion logam. Semakin lama proses adsorpsi berlangsung maka presentase adsorpsi tidak akan mengalami kenaikan, hal ini disebabkan bahan penyerap telah jenuh, sehingga perpanjangan waktu tidak akan mempengaruhi presentase adsorpsi.

Jumlah adsorben akan mempengaruhi waktu setimbang dimana semakin banyak jumlah adsorben yang digunakan maka akan semakin lama waktu setimbang dicapai. Hal ini disebabkan kesesuaian dari ukuran molekul ion logam dengan pori adsorben. Dengan demikian, waktu setimbang akan semakin lama tercapai (Nurhasni dkk, 2012)

Penentuan berat optimum adsorben pada adsorpsi ion $\mathrm{Cu}$ (II) oleh serbuk gergaji kayu jati

Penentuan berat optimum pada penelitian ini dilakukan mulai dari 0,5, 1,0, dan 1,5 gram, dengan konsentrasi larutan $\mathrm{Cu}$ yang digunakan adalah 50 ppm dan waktu pengocokkan 30 menit (waktu optimum) yang diperoleh dari perlakuan sebelumnya. data penentuan pengaruh massa adsorpsi ion $\mathrm{Cu}(\mathrm{II})$ Oleh serbuk gergaji kayu jati dapat dilihat pada Tabel 2.

\begin{tabular}{cc}
\hline Massa Adsorben (gram) & Cu terserap (\%) \\
\hline 0,5 & 93,678 \\
1,0 & 92,964 \\
1,5 & 96,176 \\
\hline
\end{tabular}

Tabel 2. Hasil Penentuan pengaruh Massa Adsorpsi Ion Cu (II)

Tujuan dari penentuan berat optimum adsorben adalah untuk mengetahui jumlah minimum adsorben yang dapat digunakan untuk proses adsorpsi, sehingga jumlah penggunaan adsorben lebih efisien. Pada penelitian ini, konsentrasi $\mathrm{Cu}$ yang digunakan 50 ppm sebanyak $25 \mathrm{~mL}$, dan waktu kontak 30 menit. Dimana data penentuan berat optimum adsorben dapat dilihat pada Tabel 4.2. berdasarkan data tersebut maka presentase adsorpsi pada berbagai berat adsorben dapat kita ilustrasikan seperti pada Gambar 2.

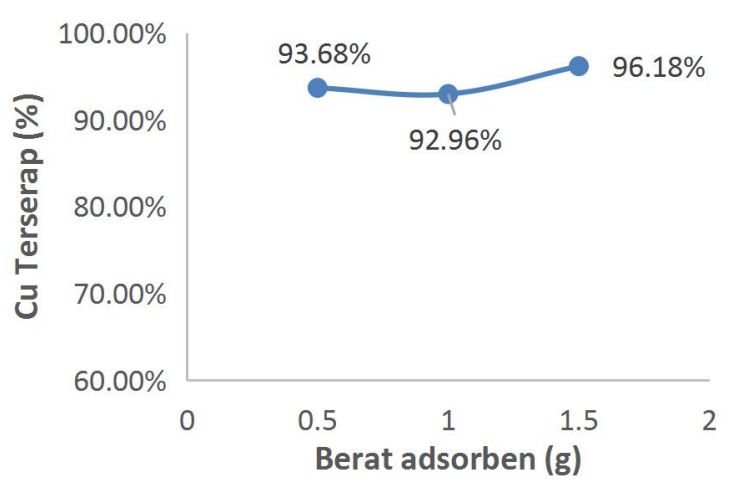

Gambar 2. Kurva hubungan antara berat adsorben terhadap \% Cu (II) terserap

Berdasarkan Gambar 2 kita ketahui bahwa massa adsorben yang digunakan berpengaruh terhadap jumlah ion $\mathrm{Cu}$ yang terserap, semakin besar jumlah adsorben yang digunakan maka jumlah ion $\mathrm{Cu}(\mathrm{II})$ yang terserap juga semakin bertambah, hubungan antara massa adsorben dan presentase efektivitas adsorpsi berbanding lurus juga ditunjukkan oleh penelitian Pratama 
(2017:134), dimana semakin besar massa adsorben ampas teh yang digunakan maka presentase efektivitas adsorpsi logam juga semakin tinggi. Dilihat pada kurva di atas pada berat 1,5 gram terjadi penaikan presentase yaitu $96,18 \%$, hal ini disebabkan karena semakin banyak massa adsorben yang digunakan maka jumlah pori yang digunakan untuk menjerap ion logam juga semakin bertambah. Banyaknya jumlah pori yang tersedia akan memberikan banyak ruang bagi adsorben untuk mengadsorpsi ion logam sehingga akan berakibat terhadap peningkatan daya adsorpsi.

Penelitian sebelumnya menyatakan bahwa konsentrasi ion logam yang tersisa didalam larutan semakin menurun dengan bertambahnya jumlah adsorben yang digunakan. Hal ini disebabkan semakin banyak jumlah adsorben yang digunakan maka akan meningkatkan jumlah partikel dan luas permukaan sehingga menyebabkan jumlah tempat mengikat ion logam bertambah dan efisiensi adsorpsinya pun meningkat (Nurhasni dkk,2012). Istighfarini (2017:5) juga menjelaskan bahwa semakin kecil ukuran diameter adsorben, maka luas permukaan kontak adsorben dengan logam semakin besar, selain itu luas permukaan kontak adsorben juga berbanding lurus dengan banyak pori yang dimiliki per satuan partikel pori.
Penyerapan adsorben menjadi lebih baik disebabkan karena ukuran partikel adsorben yang kecil mempunyai tenaga inter molekuler yang besar. Oleh karena itu, semakin banyak jumlah adsorben yang digunakan maka semakin menurun konsentrasin ion logam yang tersisa didalam larutan sehingga semakin meningkat presentase adsorpsinya.

Bila permukaan sudah jenuh atau mendekati jenuh terhadap adsorbat, dapat terjadi dua hal yaitu yang pertama terbentuk lapisan adsorpsi kedua dan seterusnya diatas adsorbat yang telah terikat dipermukaan, gejala ini dapat disebut adsorpsi multilayer, sedangkan yang kedua tidak terbentuk lapisan kedua dan seterusnya sehingga adsorbat yang belum teradsorpsi berdifusi keluar pori dan kembali ke arus fluida.

\section{Penentuan kapasitas adsorpsi ion $\mathrm{Cu}$ (II) oleh serbuk gergaji kayu jati}

Penentuan kapasitas pada penelitian ini dilakukan mulai dari 50 ppm, 100 ppm, 150 ppm, dan 200 ppm, dimana waktu pengocokan yang digunakan adalah 30 menit (waktu optimum) dan berat adsorben 1,5 gram (berat optimum) yang diperoleh dari perlakuan sebelumnya. Data penentuan kapasitas biosorpsi ion $\mathrm{Cu}(\mathrm{II})$ oleh serbuk gergaji kayu jati dapat dilihat pada Tabel 3.

\begin{tabular}{cc}
\hline Konsentrasi $(\mathbf{m g} / \mathbf{L})$ & Kapasitas adsorpsi $\mathbf{( m g / g )}$ \\
\hline 50 & 0,793 \\
100 & 1,426 \\
150 & 1,883 \\
200 & 2,058 \\
\hline
\end{tabular}

Tabel 3. Hasil Penentuan Kapasitas Adsorpsi Ion Cu (II)

Pada penentuan kapasitas adsorpsi dilakukan dengan membuat variasi konsentrasi 50. 100, 150, dan $200 \mathrm{mg} / \mathrm{L}$, yang dicampurkan dengan 1,5 gram adsorben menggunakan waktu kontak 30 menit. Konsentrasi merupakan faktor yang tidak kalah penting dalam proses adsorpsi. Kemampuan penjerapan suatu adsorben dipengaruhi oleh konsentrasi dari larutan ion logam tersebut.
Perbedaan konsentrasi akan mempengaruhi jumlah ion logam yang terdapat dalam larutannya. Semakin besar konsentrasi suatu larutan, maka semakin banyak pula ion logam yang terkandung di dalamnya dan akan mempengaruhi proses adsorbsi.(Susilawati, dkk, 2015) Efektivitas adsorpsi variasi konsentrasi ditunjukan pada Gambar 3

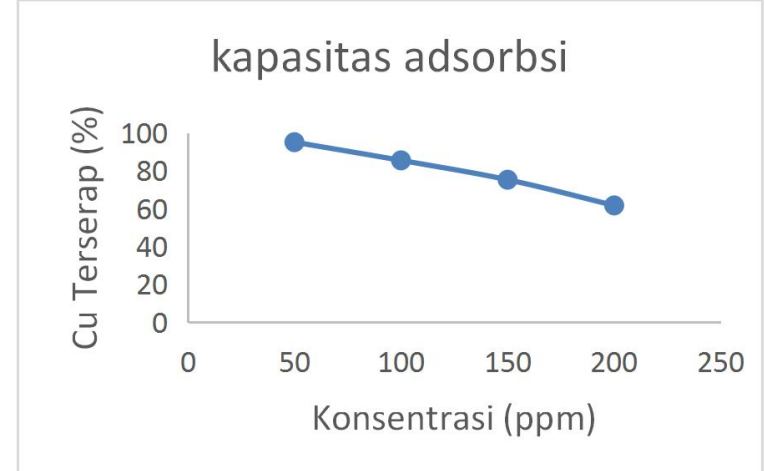

Gambar 3. Kurva hubungan antara konsentrasi awal dengan kapasitas adsorpsi Cu (II)

Gambar 3. menunjukan efektivitas adsorpsi pada rentang konsentrasi yang digunakan, jumlah ion $\mathrm{Cu}(\mathrm{II})$ yang diadsorpsi masih terus bertambah yang berarti adsorben belum jenuh. Konsentrasi 
awal ion logam berkaitan dengan jumlah gugus yang aktif pada permukaan adsorben, jika jumlah gugus yang aktif cukup besar dan tidak sebanding dengan jumlah konsentrasi logam berat maka kapasitas penyerapan adsorben akan tinggi. Tetapi jika jumlah gugus aktif sama dengan jumlah konsentrasi logam berat maka kapasitas penyerapan akan menurun. Hal ini karena konsentrasi awal ion logam menunjukkan jumlah ion logam yang terdapat dalam larutan (Zubaidah et al., 2017). Penentuan kapasitas adsorpsi maksimum dilakukan dengan menggunakan isotermal Langmuir dan Freundlich

\section{Isoterm adsorpsi}

Berdasarkan data pada tabel 3 dan persamaan bentuk linear isotherm Langmuir dan Freundlich diperoleh kurva isoterm adsorpsi seperti tertera pada gambar 4 dan 5 .

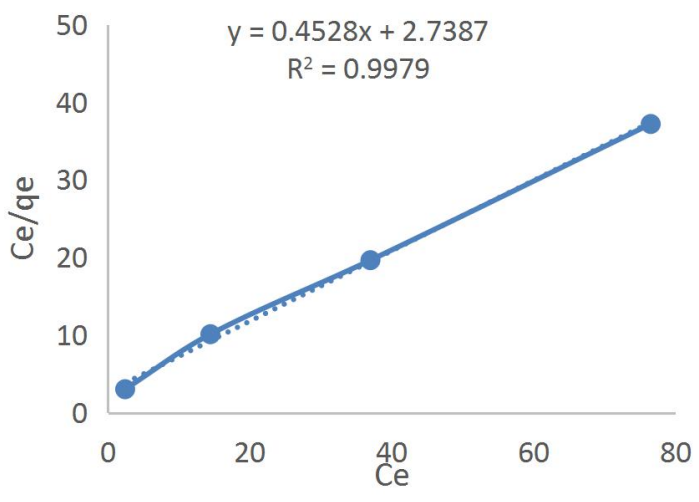

Gambar 4. Kurva linearitas isoterm Langmuir $\mathrm{Cu}(\mathrm{II})$

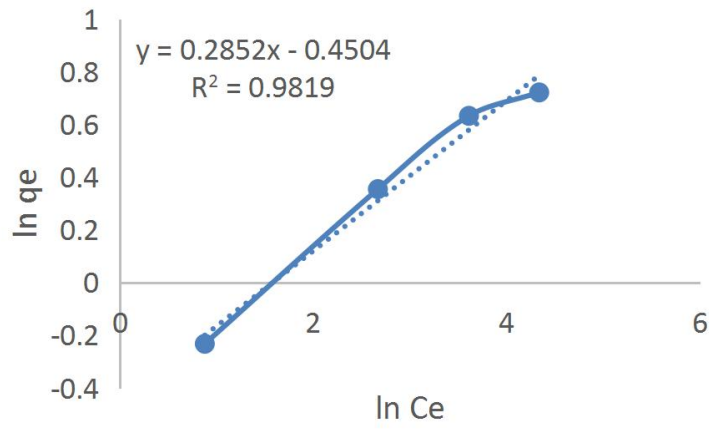

Gambar 5. Kurva linearitas isoterm Freundlich $\mathrm{Cu}(\mathrm{II})$

\begin{tabular}{|ccc|ccc|}
\hline \multicolumn{3}{|c|}{ Langmuir } & \multicolumn{3}{c|}{ Freundlich } \\
\hline $\mathrm{q}_{\max }$ & $\mathrm{K}_{\mathrm{L}}$ & $\mathrm{R}^{2}$ & $\mathrm{~N}$ & $\mathrm{~K}_{\mathrm{F}}$ & $\mathrm{R}^{2}$ \\
2,05 & 0,18 & 0,9979 & 3,51 & 0,64 & 0,9819 \\
& & & & & \\
\hline
\end{tabular}

Tabel 4. Data Isoterm Adsorpsi Serbuk Gergaji Kayu Jati

Berdasarkan data yang ditunjukkan pada Tabel 4 dapat ditentukan pola adsorpsi ion logam $\mathrm{Cu}(\mathrm{II})$ oleh serbuk gergaji kayu jati dengan membandingkan nilai koefisien regresi linear $\left(R^{2}\right)$ dimana dari kurva isoterm adsorpsi Langmuir diperoleh nilai koefisien regresi linear yaitu 0,9979 sedangkan untuk isoterm adsorpsi Freundlich sebesar 0,9819. Ditinjau dari nilai $R^{2}$, model adsorpsi ion logam $\mathrm{Cu}(\mathrm{II})$ oleh serbuk gergaji kayu jati lebih sesuai dengan Isoterm Langmuir dibandingkan dengan Isoterm freundlich. Hal ini membuktikan bahwa permukaan serbuk gergaji kayu jati memiliki sisi aktif pada permukaan yang bersifat homogen.Selain itu nilai $b\left(K_{L}\right)$ atau konstanta Langmuir pada penelitian ini yaitu 0,018 .

Nilai $\mathrm{n}$ pada isoterm freundlich merupakan konstanta Freundlich, dimana nilai ini menunjukan karakteristik adsorpsi. Kesesuain sangat baik apabila nilainya 2-10, cukup apabila nilainya 1-2 dan buruk apabila nilaimnya <1 (Rasmiah,2013). Nilai konstanta Freundlich pada penelitian ini adalah $0,64 \mathrm{mg} / \mathrm{L}$, nilainya diatas 2 dan mengidentifikasikan proses biosorpsi sangat baik. Nilai $Q_{0}$ (kapasitas biosorpsi maksimum) yang 
diperoleh menurut pola isoterm Langmuir yaitu $2,05 \mathrm{mg} / \mathrm{g}$ dan sangat mendekati hasil eksperimen $(2,058 \mathrm{mg} / \mathrm{g})$.

Berdasarkan hasil penelitian, kedua model isoterm ini cocok digunakan pada penyerapan ion logam $\mathrm{Cu}(\mathrm{II})$ oleh serbuk gergaji kayu jati karena harga R2 mendekati 1. Hal yang sama juga diperoleh Ahmad, dkk. (2009) yaitu isoterm Langmuir dan Freundlich cocok diterapkan pada adsorpsi ion timbal(II) menggunakan serbuk gergaji kayu meranti. Namun jika dibandingkan nilai R2 pada isoterm Langmuir dan Freudlich terlihat bahwa isoterm Langmuir lebih cocok digunakan pada penyerapan ion logam $\mathrm{Cu}$ (II) oleh serbuk gergaji kayu jati karena nilai R2 pada isoterm Langmuir lebih besar dari isoterm Freundlich.

Kesesuaian pola adsorpsi ion $\mathrm{Cu}(\mathrm{II})$ pada serbuk gergaji kayu jati hasil eksperimen dengan teoritis dapat dilihat pada kurva perbandingan kapasitas adsorpsi (qe) antara hasil eksperimen dengan model isotherm Langmuir dan Freundlich seperti tertera pada Gambar 6.

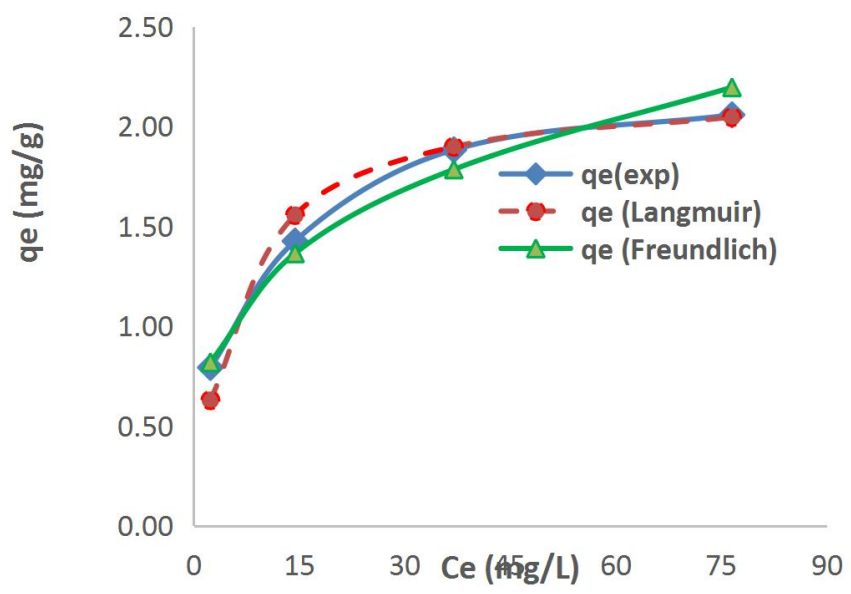

Gambar 6. Kurva Perbandingan Kapasitas Adsorpsi

\section{KESIMPULAN}

Kesimpulan yang diperoleh dari penelitian ini adalah sebagai berikut :

1. Waktu optimum adsorpsi ion $\mathrm{Cu}$ (II) serbuk gergaji kayu jati yaitu 30 menit, dengan berat ion $\mathrm{Cu}(\mathrm{II})$ yang terserap sebesar 0,760 $\mathrm{mg} / \mathrm{g}$ dan presentase adsorpsi ion $\mathrm{Cu}(\mathrm{II})$ yang terserap yaitu $91,25 \%$

2. Berat optimum adsorpsi ion $\mathrm{Cu}$ (II) serbuk gergaji kayu jati yaitu 1,5 gram, dengan berat ion $\mathrm{Cu}(\mathrm{II})$ yang terserap sebesar 0,801 $\mathrm{mg} / \mathrm{g}$ dan presentase adsorpsi ion $\mathrm{Cu}(\mathrm{II})$ yang terserat yaitu $96.176 \%$

3. Berdasarkan nilai $Q_{0}$ yang diperoleh dari persamaan Langmuir kapasitas adsorpsi optimum ion $\mathrm{Cu}$ (II) sebesar $2,05 \mathrm{mg} / \mathrm{g}$

\section{UCAPAN TERIMA KASIH}

Penulis mengucapkan terima kasih kepada pihak - pihak yang telah banyak membantu, khususnya kepala laboratorium, laboran laboratorium kimia FKIP Universitas Tadulako, dan Laboratorium Kesehatan Kota Palu telah memberikan kesempatan kepada penulis untuk melakukan penelitian sehingga penelitian ini berjalan dengan lancar.

\section{DAFTAR PUSTAKA}

Ahmad, A., Chii, Y.Y., Ibrahim, M.H., Rafatullah, M., Siddique, B.M., \& Sulaiman, O.
(2009). Removal of $\mathrm{Cu}(\mathrm{II})$ and $\mathrm{Pb}(\mathrm{II})$ ions from aqueous solutions by adsorpsion on sawdust of meranti wood. Desalination, 247:636-646.

Deng, S., Wanga,D.P., Zhangb, G., \& DoucaState, Y. (2016). Polyacrylonitrile-based fiber modified with thiosemicarbazide by microwave irradiation and its adsorption behavior for $\mathrm{Cd}(\mathrm{II})$ and $\mathrm{Pb}(\mathrm{II})$. Journal of Hazardous Materials, 307:64-72.

Irawati, D. A. (2016). Pengaruh ion logam Cu (II) terhadap persen ekstraksi ion $\mathrm{Pb}$ (II) menggunakan teknik emulsi membran cair. Jurnal Akademika Kimia. 5(4): 172177

Erawati.E, \& Fernando, A. (2018). Pengaruh jenis aktivator dan ukuran karbon aktif terhadap pembuatan adsorbent dari serbuk gergaji kayu sengon (Paraserianthes Falcataria). Jurnal Integrasi Proses, 7(2), 58-66

Fatmi, D., \& Putra, B.H. (2018). Studi efektifitas limbah kulit pisang (Musa acuminate) sebagai biosorben logam berat seng (Zn). Menara IImu. 12(9).

F. Fu, Q. Wang. (2011). Removal of heavy metal ions from wastewaters: A review, Journal of Environmental

Management, 92, 2011, 407-418 
Garba, Z.N., Bello, I., Galadima, A., Lawal, Y.A. (2016). Optimization of adsorption conditions using central composite design for the removal of copper (II) and lead (II) by defatted papaya seed. Karbala International Journal of Modern Science, 2:20-28.

Gultom,E.M dan Lubis,M.T. (2014). Aplikasi karbon aktif dari cangkang kelapa sawit dengan aktivator $\mathrm{H}_{3} \mathrm{PO}_{4}$ untuk Penyerapan logam berat $\mathrm{Cd}$ dan $\mathrm{Pb}$ Jurnal teknik kimia USU. 3 (1), 5-10.

Handayani, M., dan Sulistiyono, E. (2009). Uji persamaan langmuir dan freundlich pada penyerapan limbah crom $(\mathrm{VI})$ oleh ziolit. prosiding seminar nasional sains dan teknologi nuklir. Bandung: PTNBR-Batan, 130-136.

Hawari, A. H., and Catherine N.M., (2006), Biosorption of lead(II), cadmium(II), copper(II) and nickel(II) by anaerobic granular biomass. Bioresource Technal, 97: 692-700.

Hengky, S.I.T. dan Dewi, U.R. (2009). Pembuatan asap cair dari limbah serbuk gergajian kayu meranti sebagai penghilang bau lateks, Jurnal Teknik Kimia. I. (16). 1-9

Intan.D, Irwan Said, dan Paulus H. Abram. (2016). Pemanfaatan biomassa serbuk gergaji sebagai penyerap logam timbal. Jurnal Akademika Kimia, 5(4), 166-171

Istighfarini, S. A. E., Daud, S., \& Hs, E. 2017. Pengaruh massa dan ukuran partikel adsorben sabut kelapa terhadap efisiensi penyisihan Fe pada air gambut. Jurnal Online Mahasiswa Fakultas Teknik Universitas Riau, 4(1), 1-8.

Kollman, F. dan Cote,J,R. (1968). Principles of Woods Science and Technology $I$. Solid Wood. New York

Lelifaji, 2010, Adsorpsi ion logam Cu(II) menggunakan lignin dari limbah serbuk kayu gergaji, Jurnal Rekayasa Kimia dan Lingkungan , 7(3): 126-129.

Mandasari, I, Purnomo,A. (2016). Penurunan ion besi $(\mathrm{Fe})$ dan mangan $(\mathrm{Mn})$ dalam air dengan serbuk gergaji kayu kamper. Surabaya : Jurnal Teknik ITS, 5(1), 2337-2359

Mohadi, , Nurlisa Hidayati, Adi Saputra, dan Aldes Lesbani (2014). Studi interaksi ion logam $\mathrm{Mn2+}$ dengan selulosa dari serbuk gergaji kayu. Jurnal Kimia, 8(1): 1-8.

Mohadi.R, Nurlisa Hidayati, Adi Saputra, dan Aldes Lesbani, (2013). Kajian interaksi ion $\mathrm{Co}^{2+}$ dengan selulosa dari serbuk gergaji kayu. Jurnal Kimia, 1(2).

Mutiara, T.; Fajri, R.; Nurjannah, I., Karakterisasi karbon aktif dari serbuk Kayunangka limbah industri penggergajian dan evaluasi kapasitas penyerapan dengan methylene blue number, 2016, Tenoin, 22(6), 452460.

Niluh Eka Susilawati,dkk. (2015). Biocharcoal dari serbuk gergaji kayu cempaka (Elmerrillia ovalis Miq) serta daya Adsorpsinya Pada Zink dan

Akademika Kim. 4(2): 71-77

Tembaga. J.

Nurhasni, Florentinus, F. \& Qosim S. (2012). Penyerapan ion aluminium dan besi dalam larutan sodium silikat menggunakan karbon aktif.Valensi 2(4), 516-525.

Palar, H., 1994, Pencemaran dan Toksikologi Logam Berat, Bina Rupa Aksara, Yogyakarta, 97-98.

Pratama, D. A. 2017. Efektivitas ampas teh sebagai adsorben alternatif logam $\mathrm{Fe}$ dan $\mathrm{Cu}$ pada air sungai Mahakam. Jurnal Integrasi Proses, 6(3).

Purwaningsih, D., (2009). Adsorpsi multi logam $\mathrm{Ag}(\mathrm{I}), \mathrm{Pb}(\mathrm{II}), \mathrm{Cr}(\mathrm{III}), \mathrm{Cu}(\mathrm{II}) \quad$ danNi(II) pada silika dari abu sekam padi. Jurnal Penelitian Saintek, 14(1): $\quad$ 59-76.

Rudy Christiyanto Pongenda,dkk (2015). Biocharcoal dari biji salak (Salacca edulis) sebagai adsorben terhadap kromium. Jurnal. Akademika Kim. 4(2): 84-90

Santi., Tiwow, V.M.A., dan Gonggo, S.T. (2017). Analisis tembaga $(\mathrm{Cu})$ dan timbal $(\mathrm{Pb})$ dalam air laut dan sedimen di perairan pantai loli kecamatan banawa kabupaten donggala. Jurnal Akademika Kimia. 6(4) $241-246$.

Siti Zubaidah, Ibnu Khaldun, Latifah Hanum, (2017). Uji daya serap serbuk gergaji kayu pinus (Pinus mercusii) terhadap logam timbal (II) menggunakan metode spektrofotometri serapan atom (SSA). Jurnal IImiah Mahasiswa Pendidikan Kimia (JIMPK). 2(2), 107-166)

Soeprijanto, Achmad Elsony dan Eko Sulistyowati, 2004, Kinetika biosorpsi ion logam berat $\mathrm{Cr}(\mathrm{VI})$ menggunakan biomassa saccharomyces cerevisiaehal $1-9$.

Suarsa, I. W. (2016). Adsorbsi logam berat $\mathrm{Pb}$ (II), $\mathrm{Cr}(\mathrm{VI}), \mathrm{Zn}$ (II), Cd (II), Cu (II), dan Ni (II) dengan abu sekam padi. Skripsi. Denpasar : Universitas Udayana. Tidak Dipublikasikan

Suprihatin, Erriek A. (2009). Biosorpsi logam Cu (II) dan $\mathrm{Cr}$ (IV) pada limbah elektroplating dengan

menggunakan biomassa phanerochaete chrysosporium, 4(1)

Tangio J.S. (2013). Adsorpsi logam timbal (Pb) dengan menggunakan biomassa eceng gondok (Elehhorniacrassipes).Jurnal Kimia. 8,(1), 501-506.

Teker, M., İmamoĞlu, M., dan Saltabas, Ö., 1999, Adsorption of copper and cadmium lons 
by activated carbon from rice hulls, Turk. Jurnal Chem., 23, 185-191.

Vogel, G., 1985, Analisa anorganik kuantitaif makro dan semi mikro. Longman Scientific \& Technical, Vol. 1, London.

Wardani, R.A.K, Jumiati, dan Dewi Puspita Sari. 2017. Pemanfaatan limbah gergaji kayu sebagai media tanam jamur dan kain perca untuk bahan baku dalam packaging Fung - Cube. 14(1), 83-87

Widodo. (2008). Pencemaran air raksa $(\mathrm{Hg})$ sebagai dampak pengolahan bijih emas di sungai Ciliunggunung, Waluran, Kabupaten Sukabumi. Jurnal Geologi Indonesia, 3(3), 139-149. 